\title{
The control of male fertility by spermatid-specific factors: searching for contraceptive targets from spermatozoon's head to tail
}

\author{
Su-Ren Chen ${ }^{\star, 1}$, Aalia Batool ${ }^{1,2}$, Yu-Qian Wang ${ }^{1,2}$, Xiao-Xia Hao ${ }^{1,2}$, Chawn-Shang Chang ${ }^{3}$, C Yan Cheng ${ }^{4}$ and Yi-Xun Liu ${ }^{*, 1}$
}

Male infertility due to abnormal spermatozoa has been reported in both animals and humans, but its pathogenic causes, including genetic abnormalities, remain largely unknown. On the other hand, contraceptive options for men are limited, and a specific, reversible and safe method of male contraception has been a long-standing quest in medicine. Some progress has recently been made in exploring the effects of spermatid-specifical genetic factors in controlling male fertility. A comprehensive search of PubMed for articles and reviews published in English before July 2016 was carried out using the search terms 'spermiogenesis failure', 'globozoospermia', 'spermatid-specific', 'acrosome', 'infertile', 'manchette', 'sperm connecting piece', 'sperm annulus', 'sperm ADAMs', 'flagellar abnormalities', 'sperm motility loss', 'sperm ion exchanger' and 'contraceptive targets'. Importantly, we have opted to focus on articles regarding spermatid-specific factors. Genetic studies to define the structure and physiology of sperm have shown that spermatozoa appear to be one of the most promising contraceptive targets. Here we summarize how these spermatid-specific factors regulate spermiogenesis and categorize them according to their localization and function from spermatid head to tail (e.g., acrosome, manchette, head-tail conjunction, annulus, principal piece of tail). In addition, we emphatically introduce small-molecule contraceptives, such as BRDT and PPP3CC/PPP3R2, which are currently being developed to target spermatogenic-specific proteins. We suggest that blocking the differentiation of haploid germ cells, which rarely affects early spermatogenic cell types and the testicular microenvironment, is a better choice than spermatogenic-specific proteins. The studies described here provide valuable information regarding the genetic and molecular defects causing male mouse infertility to improve our understanding of the importance of spermatid-specific factors in controlling fertility. Although a male contraceptive 'pill' is still many years away, research into the production of new small-molecule contraceptives targeting spermatid-specific proteins is the right avenue.

Cell Death and Disease (2016) 7, e2472; doi:10.1038/cddis.2016.344; published online 10 November 2016

Facts

(1) While some nations are experiencing a population explosion, others show negative growth. The future population growth rate is highly dependent on improving fertility versus contraception.

(2) Male factor infertility is a complex disorder that affects a large sector of the population; however, most its etiology and genetic testes remain largely unexplored.

(3) Few approaches other than barrier methods have been adequately developed for male contraception. Male hormonal contraception, which disrupts the entire spermatogenesis process, is not a preferred approach and will be discarded in the furture.

(4) Most of the spermiogenic genes are highly conserved between mice and humans. Thus gene ablation in mice has been a powerful tool for identifying spermatid-specific proteins essential for spermiogenesis, which might serve as potential targets of male contraception.

\section{Open questions}

(1) What are the spermatid-specific factors required for spermiogenesis and how do they control male fertility in mice? Can they be classified into different groups by their localization and function in spermatids?

(2) What do these knockout mice tell us? Which factors are likely to turn out to be the spermatid-specific targets for male contraceptives? What is the mechanism of contraceptive action, and does the 'pill' target spermiogenic process specifically and reversibly?

\footnotetext{
${ }^{1}$ State Key Laboratory of Stem Cell and Reproductive Biology, Institute of Zoology, Chinese Academy of Sciences, Beijing, China; ${ }^{2}$ University of the Chinese Academy of Sciences, Beijing, China; ${ }^{3}$ George Whipple Lab for Cancer Research, University of Rochester Medical Center, Rochester, MN, USA and ${ }^{4}$ The Mary M. Wohlford Laboratory for Male Contraceptive Research, Population Council, New York, NY, USA

${ }^{*}$ Corresponding author: S-R Chen or Y-X Liu, State Key Laboratory of Stem Cell and Reproductive Biology, Institute of Zoology, Chinese Academy of Sciences, 1 Beichen West Road, Chaoyang District, Beijing 100101, China. Tel: +86 010 64807038; Fax: +86 010 64807038; E-mail: chensuren@ioz.ac.cn or liuyx@ioz.ac.cn

Abbreviations: ART, assisted reproductive techniques; IVF, in vitro fertilization; ICSI, intracytoplasmic sperm injection; CDK, cyclin-dependent kinase; ER, endoplasmic reticulum; ADAM, a disintegrin and metallopeptidase; $\mathrm{ZP}$, sperm-zona pellucida; $\mathrm{NHE}, \mathrm{Na}^{+} / \mathrm{H}^{+}$exchanger; $\mathrm{pHi}$, intracellular pH; CatSper, cation channel of sperm; $I_{\text {CatSper }}$, intracellular $\mathrm{Ca}^{2+}$-selective current; ATP, adenosine triphosphate; BRDT, bromodomain, testis-specific

Received 02.7.16; revised 18.9.16; accepted 26.9.16; Edited by M Agostini
} 
(3) Many genes have been shown to be associated with spermiogenesis in mice using knockout mouse models. However, the majority of mouse model studies fail to identify a mutation in infertile human males. Thus are the rodent models physiologically relevant to humans?

As many as $15 \%$ of human couples are infertile, and male infertility is associated with about half of these cases. ${ }^{1}$ The inability to procreate is frequently considered a personal tragedy and a curse for the couple, impacting on the entire family and even the local community. ${ }^{2}$ Currently, the pathophysiological mechanisms of male infertility are so poorly understood that most infertile men receive a description of 'idiopathic oligo/asthenozoospermia' rather than a diagnosis; hence, specific medical treatment is not possible. ${ }^{3}$ Hormonal therapy has an important but limited role as an effective treatment of gonadotrophin deficiency but no established role in empirical therapy. ${ }^{3}$ Although assisted reproductive techniques (ART), such as in vitro fertilization (IVF) and intracytoplasmic sperm injection (ICSI), allow men with suboptimal sperm quality to overcome natural selection mechanisms and produce a viable zygote, the advent of ART has emphasized the necessity and importance of elucidating the genetic basis of male infertility because inheritance of mutations passed on through ART can cause unacceptable serious consequences. ${ }^{4-6}$ Given that many non-obstructive causes of male infertility are unexplained and the therapeutic effect is beyond the power of hormone and ART, focussing on genetic causes and identifying genes and pathways associated with infertility becomes a public health priority. ${ }^{7}$ On the other hand, few approaches other than barrier methods have been adequately developed for male contraception. Male hormonal contraception, which disrupts the entire spermatogenesis process, is not a preferred approach as this may lead to other long-term health issues in men. ${ }^{8}$

Basic reproductive research has advanced fundamental knowledge about the process and genetics of spermatogenesis. Spermatogenesis can be divided into three main phases: mitotic, meiotic, and haploid spermatid development. ${ }^{9}$ In the mitotic phase, spermatogonial stem cells proliferate and differentiate into differentiating spermatogonia, which subsequently enter the meiotic phase and transform into spermatocytes. ${ }^{10}$ Spermatocytes undergo two consecutive meiotic cell divisions to produce haploid spermatids. Spermatids then experience a multistep differentiation process and undergo dramatic morphological, molecular and cellular alterations via spermiogenesis to form spermatozoa. ${ }^{11}$ Although these transformations are well defined at the morphological level in most species including humans, the underlying mechanisms that regulate these intricate processes are largely unknown. Disruptions in either the mitotic or the meiotic phase tend to cause azoospermia or severe oligospermia, whereas spermiogenic defects often lead to reduced sperm counts, aberrant sperm motility and deformed spermatozoa. ${ }^{11}$

Knockout mouse models and $N$-ethyl- $N$-nitrosourea mutagenesis presenting with an infertile phenotype, such as spermiogenesis defects, are powerful tools with which to characterize new players in spermatid development, to determine the causes of idiopathic infertility and to develop novel therapeutic approaches for male infertility. ${ }^{12,13}$ Most of the spermiogenic genes are highly conserved between mice and humans. If specific inhibitors for sperm functions can be developed for human spermatids, they would represent a new class of contraceptives that would not require disruption of early spermatogenic cell types and the testicular microenvironment. This gene-based therapies directed against the underlying cause and mechanisms of male infertility would also specifically target men with known disorders of spermatogenesis. In conjunction with improved ICSI/IVF, this novel method will offer the greatest hope for male infertility therapy.

Here we describe the currently known spermatid-unique genes involved in each of the major steps of spermiogenesis and summarize their functions in knockout mouse models. We will also discuss the mechanism, specificity, reversibility and shortcomings of emerging contraceptive 'pill'.

\section{Globozoospermia-related proteins: roles in acrosome}

Although the acrosome is known to be derived from the Golgi apparatus and its biogenesis involves three consecutive phases, the molecular mechanisms underlying acrosome formation remain largely unknown. ${ }^{14,15}$ Globozoospermia (a condition that causes $\sim 0.1 \%$ of cases of human infertility) is characterized by round-headed spermatozoa that lack an acrosome (Figure 1a), and human mutants and mouse strains presenting with such a defect represent very valuable models to decipher acrosome biogenesis. ${ }^{16,17}$

Using knockout mouse $(-/-)$ models, a number of genes

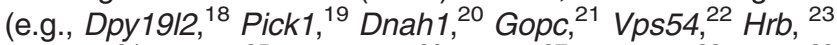

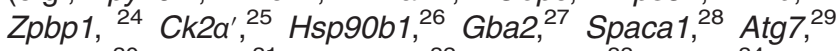
Smap2, ${ }^{30}$ Fads2, $^{31}$ Flotillin-2, ${ }^{32}$ Ccdc136, ${ }^{33}$ Pcsk4 $^{34}$ and Hiat $^{35}$ ) have been found to trigger globozoospermia. Among them, deletions and/or mutations in SPATA16, ${ }^{36,37}$ PICK $1,{ }^{38}$ $D P Y 19 L 2^{39}{ }^{39} Z P B P 1^{40}$ and $D N A H 1^{41}$ have been identified in globozoospermia patients. The involvement of the human orthologues of the other above-mentioned mouse genes in human globozoospermia requires further investigation. It may also be important to classify these globozoospermia-related proteins in terms of their diverse cellular functions (such as Golgi vesicle fusion, acrosome exocytosis, acrosome attachment and spreading over the nucleus) or phases (Golgi phase, cap phase, acrosome phase and maturation phase). Notably, PICK1, GOPC, VPS54, HRB and SPATA16 control the Golgi vesicle fusion that is necessary for acrosome formation (Figure 1b), whereas DPY19L2 regulates the attachment of the nuclear envelope to the acroplaxome ${ }^{18}$ (Figure 1c). The acrosomal matrix protein ACRBP was recently identified as another globozoospermia-related protein to regulate acrosomal granule formation. ${ }^{42}$

It is cautious to that only a limited number of studies focus on the interaction and regulation among these globozoospermiarelated proteins. Pcsk4-null sperm exhibit low expression of ACRBP. ${ }^{34}$ ATG7 regulates GOPC during acrosome biogenesis. ${ }^{29}$ The levels of ZPBP1 and SPACA1 are extermely low in the $\mathrm{Gopc}^{-1-}$ mouse testes. ${ }^{28}$ PICK1 interacts and cooperates with GOPC and CK2 $a^{\prime}$ in acrosome biogenesis. ${ }^{19}$ Recently, He et al. ${ }^{43}$ identified ICA1L as a new BAR domainbinding partner of PICK1, and sperm from $\mathrm{Ica} \mathrm{I}^{/-}$mice exhibit the characteristics of globozoospermia. 


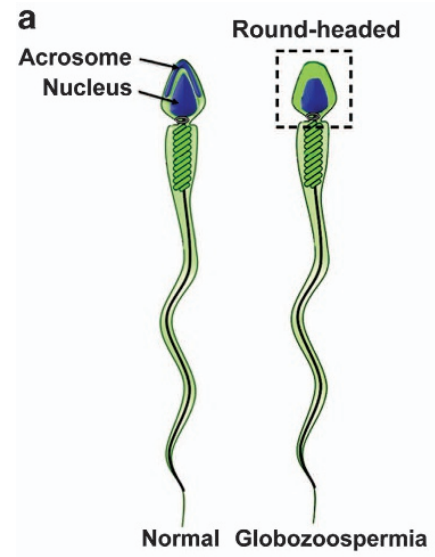

b

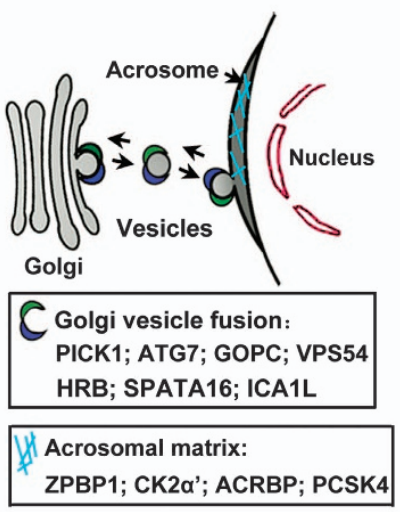

C

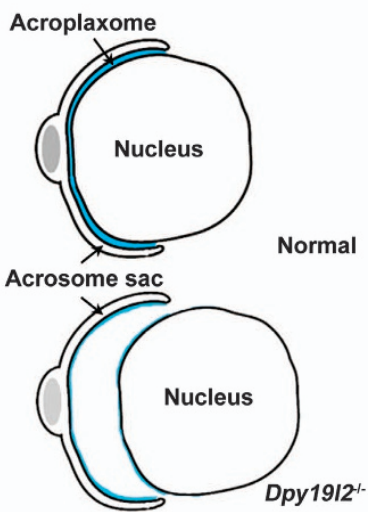

Figure 1 Model illustrating the role of some typical globozoospermia-related proteins in acrosome formation. (a) Globozoospermia is characterized by round-headed spermatozoa that lack an acrosome. (b) PICK1, ATG7, GOPC, VPS54, HRB, SPATA16 and ICA1L facilitate formation of trafficking vesicles from the Golgi apparatus to the acrosome. ZPBP1, CK2 $\alpha$, ACRBP and PCSK4 are proteins of the acrosomal matrix. (c) The absence of Dpy19/2 leads to the destabilization of the junction between the acroplaxome and the nuclear envelope

In addition to acrosome integrity, acrosomal exocytosis (also called the 'acrosome reaction') is an important event during the final phase of fertilization. ${ }^{44,45}$ We emphasize the fact that most of the identified factors also control the process of exocytosis in the somatic cells of non-reproductive tissues. In particular, AFAF (also called MN9) ${ }^{46,47}$ and SPESP1 ${ }^{48-50}$ are specifically localized in the equatorial segment of sperm. We found that $\mathrm{Afaf}^{-1-}$ male mice are subfertile and the fertilization and induced acrosome exocytosis rates of Afafnull sperm are considerably reduced. ${ }^{51,52}$ Furthermore, AFAF facilitates an interaction with Syntaxin1a and Snap25 during sperm acrosomal exocytosis. ${ }^{51,52}$ Spesp $1^{-1-}$ male mice are subfertile, partially owing to the loss of equatorial membrane after the acrosome reaction. The disruption of Spesp 1 causes aberrant expression and distribution of acrosomal protein MC101, ADAM family proteins and MN9 antigen. ${ }^{48}$ Loss of Afafor Spesp1 does not lead to complete infertility in mice, and no mutation of either of these genes is found in male infertility patients. As such, identification of spermatid-specific factors that are critical for acrosomal exocytosis is of great interest.

\section{Manchette of elongating spermatids}

The manchette is a transient skirt-like structure in the elongating spermatid head that assembles concurrently with the elongation and condensation of the spermatid nucleus and growth of the centrosome-derived axoneme. ${ }^{53}$ The basic platform of the manchette consists of microtubules, actin filaments and the associated motor protein (e.g., myosin). ${ }^{54}$ Next, we introduced the several manchette-specific protein complexes and the consequences of their disruption in spermatid elongation (Figure 2).

Mns1-deficient males are sterile, exhibiting a sharp reduction in sperm production, and the remnant sperm are immotile with abnormal short and crooked tails. ${ }^{55}$ A subsequent study has shown that MNS1 colocalizes with the motor protein KIF3A in the manchette and the principal piece of the sperm tail. Phenocopying $M n s 1^{-1-}$, a germ cell-specific depletion of Kif3a, affects sperm tail formation, manchette organization

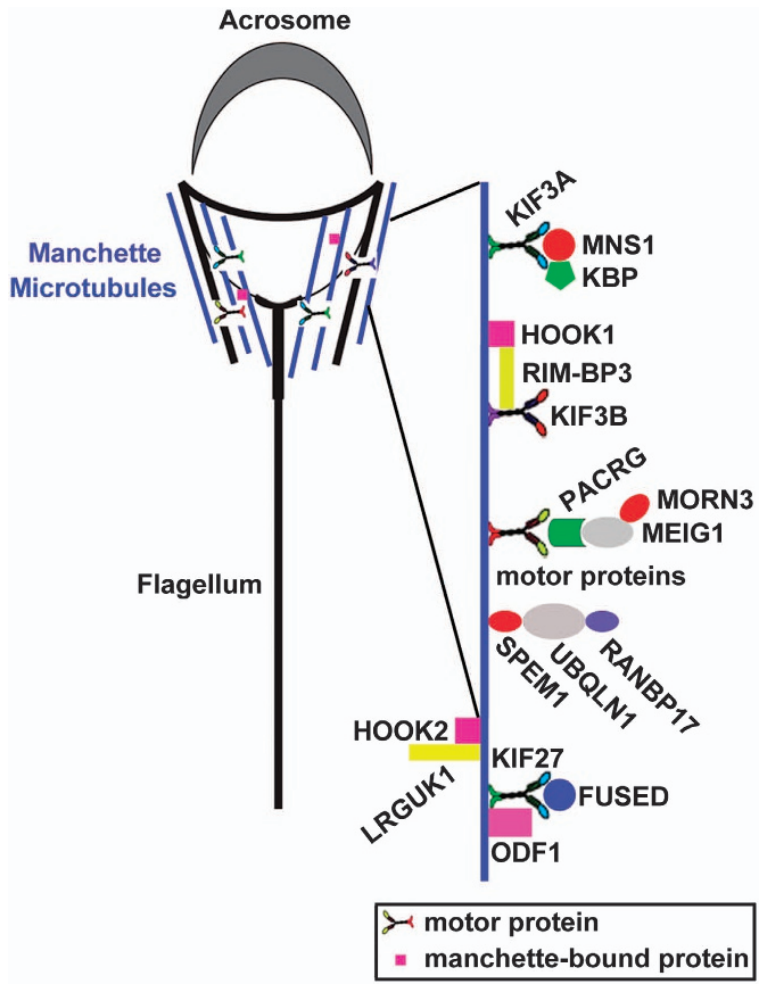

Figure 2 Model illustrating three typical protein complexes that leech on to manchette microtubules. The manchette is a transient skirt-like structure surrounding the elongating spermatid head and is only present during spermatid elongation. In the KIF3A/MNS1/KBP complex, MNS1 co-localizes and interacts with the KIF3A motor protein and KBP in the manchette. In the HOOK1/RIM-BP3/KIF3B complex, the RIMBP3 protein physically associates with the manchette-bound protein HOOK1 and KIF3B motor protein. In the MORN3/MEIG1/PACRG/motor complex, the MEIG1 and PACRG form a complex and PACRG then associates with the manchette microtubules through motor protein(s). MEIG1 also interacts with the manchetteexpressed protein MORN3. In the SPEM1/UBQLN1/RANBP17 complex, the SPEM1 interacts with UBQLN1 and RANBP17 in the manchette of elongating spermatids. LRGUK1 binds to HOOK2 to regulate manchette function. In the KIF27/FUSED/ ODF1 complex, the FUSED interacts with the outer dense fibre protein ODF1 and manchette-expressed kinesin KIF27 


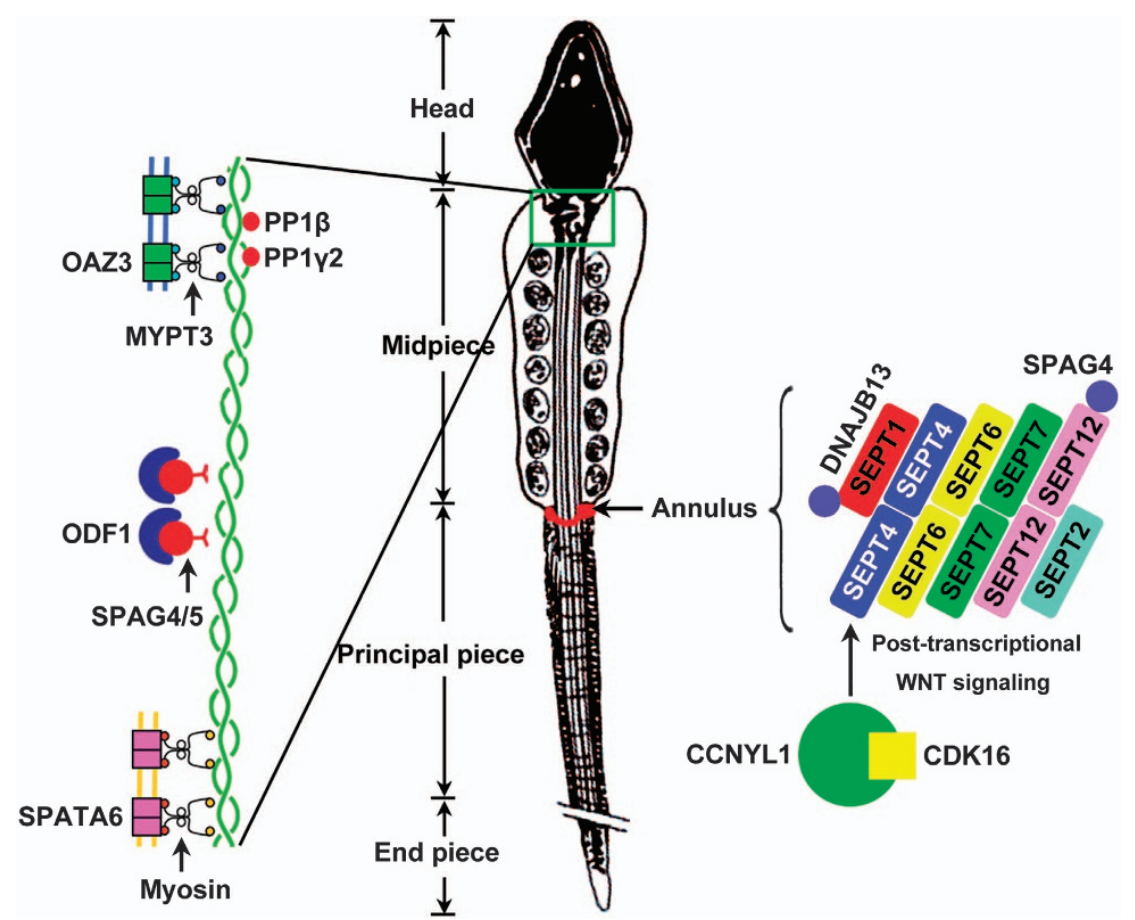

Figure 3 Schematic diagram of the myosin-based connecting piece and the septin-based annulus. The sperm head and tail are bridged by the connecting piece (green box), while the annulus (red structure) connects the midpiece and the principal piece of the mammalian sperm flagellum. Through interaction with myosin subunits, many factors (e.g., OAZ3, ODF1 and SPATA6) participate in the myosin-based microfilament formation and/or maintenance, which is responsible for formation of the connecting piece. Oaz3encoded protein 12 interacts with MYPT3 to modulate the activity of protein phosphatase PP1 $\beta$ and PP1 $\gamma 2$. Linking of ODF1 to microtubules might occur via ODF1/SPAG5/ SPAG4 interaction. SPATA6 forms a complex with myosin light and heavy chain subunits (e.g., MYL6) during connecting piece formation. The annulus is a complex of septins (SEPT) 1, 2, 4, 6, 7 and 12. These septin complexes are associated with the cochaperone DNAJB13 and SPAG4 specifically interacts with SEPT12. The CCNYL1/CDK16 complex also determines the structure and function of the annulus through posttranscriptional WNT signalling and GSK-mediated SEPT4 clustering in the epididymis

and the shaping of sperm heads. ${ }^{56} \mathrm{KIF} 3 \mathrm{~A}$ also interacts with a KIF1-binding protein (KBP) in the manchette of elongating spermatids ${ }^{57}$; however, the role of KBP in spermatid elongation remains unknown.

Rimbp3 (the gene encoding RIM-BP3) mutant mice display ectopic positioning of the manchette within the spermatid, a presumed cause of sperm head deformities ${ }^{58}$ Consistent with its role in morphogenesis, the RIM-BP3 protein physically associates with HOOK1, a known manchette-bound protein required for sperm morphogenesis. ${ }^{58-60}$ RIM-BP3 may modulate the interaction of HOOK1 with certain organelles to which the manchette should be anchored. KIF3B, a kinesin family member, was identified as another RIM-BP3-interacting partner in a yeast two-hybrid screen. ${ }^{58}$

Meig1 mutant male mice are sterile as a result of disrupted manchette structure and impaired sperm elongation and condensation. ${ }^{61}$ PACRG interacts with MEIG1, and Pacrg knockout also impairs manchette structure. ${ }^{61}$ MORN3, expressed in the manchette of the elongating spermatid, was recently identified as another MEIG1-interacting protein. ${ }^{62}$

LRGUK1 binds to HOOK2 and mutation of Lrguk1 leads to manchette dysfunction and, ultimately, to abnormal sperm head shaping and sterility. ${ }^{63,64}$ Sun4-deficient mice lack the linkers between the nuclear envelope and the microtubule manchette. ${ }^{65,66}$ Azi1-null spermatids show defective manchette structure and abnormal head morphologies, suggesting defects in intramanchette transport. ${ }^{67}$ Inactivation of
Spem1 in mice results in deformed spermatozoa characterized by 'head-bent-back' abnormalities and male infertility, ${ }^{68}$ and SPEM1 interacts with UBQLN $1{ }^{69}$ and RANBP $17^{70}$ in the manchette of elongating spermatids. FUSED interacts with the outer dense fibre protein ODF1 and manchette-expressed kinesin KIF27, and Fused-null spermatozoa exhibit perturbed manchette formation. ${ }^{71}$

It will be interesting to specifically disrupt the interaction of the MNS1-KIF3A-KBP, KIF3B-RIM-BP3-HOOK1, PACRGMEIG1-MORN3, LRGUK1-HOOK2 and UBQLN1-SPEM1RANBP17 complex and elucidate the physiological roles of the 'complex' in the manchette and in spermiogenesis. More mouse models affecting manchette formation can be found in other articles $^{72-76}$ and review. ${ }^{54}$

\section{Head-tail conjunction: interaction between OAZ3, ODF1, SPATA6, and myosins}

The sperm head and tail are bridged by the connecting piece, which not only serves as a physical linkage but also participates in sperm motility. ${ }^{77,78}$ 'Decapitated sperm', or 'acephalic sperm', a type of human teratozoospermia, refers to the condition in which the ejaculate contains mostly sperm tails without heads. ${ }^{79-81}$ To date, several proteins that interact with myosin (an actin-based motor protein) have been reported to contribute to the connection between the sperm head and tail (Figure 3; left). 
Oaz3 encodes ornithine decarboxylase antizyme 3 and is specifically expressed in spermatids. ${ }^{82}$ The heads and tails of Oaz3-disrupted spermatids are easily separated in culture medium during incubation. ${ }^{83}$ Although the tailless sperm failed to acrosome-react, the heads were capable of fertilizing eggs via ICSI. Ruan et al. ${ }^{84}$ further suggest that the Oaz3-encoded protein p12 interacts with myosin phosphatase targeting subunit 3 (MYPT3) to modulate the activity of protein phosphatase PP1 $\beta$ and PP1 $\gamma 2$.

Similarly, mice lacking Odf1, a gene encoding outer dense fibre protein 1 , display detachment of the sperm head. ${ }^{85}$ Haplo-deficiency of ODF1 (Odf1 $\left.{ }^{+/}\right)$in mouse sperm causes relaxation of head-to-tail linkage and severe male subfertility. ${ }^{86}$ Linking of ODF1 to microtubules might occur via ODF1/ SPAG5/SPAG4 (axoneme-binding proteins) interaction and to mitochondria via ODF1/KLC3 (kinesin light chain) interaction. ${ }^{85}$

However, neither the Oaz3- nor Odf1-deficient mice display uniformly $100 \%$ acephalic spermatozoa, suggesting that, in the absence of these genes, the connecting piece can still be formed, although in many spermatozoa it is not strong enough to maintain stability. Ablation of Spata6 (spermatogenesisassociated 6 gene) completely disrupts formation of the connecting piece, leading to acephalic spermatozoa and male sterility in mice. ${ }^{87,88}$ Interaction between SPATA6 and myosin light and heavy chain subunits (e.g., MYL6) strongly suggests that SPATA6 is involved in myosin-based microfilament transport during connecting piece formation. ${ }^{88}$ Further identification of spermatid-specific factors that control the connection of the sperm head and tail and mutation screening in human teratozoospermia patients remain to be investigated.

\section{Septin-based organization of the annulus}

The annulus is an electron-dense ring structure connecting the midpiece and the principal piece of the mammalian sperm flagellum. ${ }^{89}$ Septin-based organization of the annulus is a requisite for the structural and mechanical integrity of the annulus. The spermatozoa from a subset of human patients with asthenospermia syndrome have a commonly disorganized annulus/septin ring. ${ }^{90-92}$

The genetic loss of Sept4 in mice causes disorganization of the annulus and adjacent cortex, which results in fragility and immotility of spermatozoa. ${ }^{90,93}$ Septins $1,6,7$ and 12 co-localize with SEPT4, while SEPT12 forms a filamentous structure with septins 2, 4, 6 and 7 at the sperm annulus ${ }^{89,94}$ (Figure 3; right). These septin complexes appear to assemble in round spermatids and are associated with the cochaperone DNAJB13 ${ }^{95}$ Recently, Yeh et al. ${ }^{96}$ determined that SEPT12 colocalizes and interacts with SPAG4 (also known as SUN4) in the nuclear periphery of round spermatids and in the tail of elongating spermatids. Furthermore, $\mathrm{Tssk}^{-1-}$ mice are subfertile owing to disorganization of the midpiece-principal piece junction and significantly decreased sperm motility. ${ }^{97,98}$ TSSK4 and ODF2 can regulate each other through phosphorylation. ${ }^{98}$ In addition, Sepp $1^{-1-}$ and Tat1 $1^{-1-}$ spermatozoa had structural defects similar to those described in Sept4-null sperm, including thinning of the flagellum at the midpiece-principal piece junction and hairpin-like bending of the flagellum. ${ }^{99-101}$ However, the underlying mechanism of disorganization of the annulus in Sepp1-null and Tat1-null spermatozoa and their interaction with septins remain unknown.

Cyclins comprise a family of highly conserved proteins and exert their crucial roles by activating cyclin-dependent kinases (CDKs). Close cooperation between specific sets of cyclin/ CDK partners is of great significance. ${ }^{102,103}$ Cdk16-deficient spermatozoa display thinning and elongation of the annulus region and show impaired motility. ${ }^{104}$ Mikolcevic et al. ${ }^{104}$ suggest that CDK16 interacts with the CCNY protein; however, $\mathrm{Ccny}^{-1-}$ male mice are fertile. ${ }^{105}$ CCNYL1, which is specifically expressed in the testis, also cooperates with CDK16 at the plasma membrane of sperm. ${ }^{105}$ In contrast to Ccny-null spermatozoa, spermatozoa obtained from Ccnyl1 ${ }^{-1-}$ mice display significantly impaired motility and represent a thinned annulus region. ${ }^{105,106}$ Accordingly, CCNYL1, but not CCNY, cooperates with CDK16 to regulate the structure and function of the annulus (Figure 3; right). The CCNYL1/CDK16 complex regulates annulus development partially via non-classical WNT (wingless-related MMTV integration site) signalling and GSK-mediated SEPT4 clustering in the epididymis. ${ }^{106}$

\section{Endoplasmic reticulum (ER) quality-control system: CALR3/PDILT/ADAMs/PMIS2}

Membrane and secretory proteins are cotranslationally translocated into the ER lumen, where numerous molecular chaperones and folding enzymes assist their maturation. ${ }^{107,108}$ The testes presents a special case for the control of ER protein folding because of the unusual environment (e.g., low temperature and dramatic morphological changes of spermatids).

Calmegin (CLGN), ${ }^{109}$ angiotensin-converting enzyme, ${ }^{110}$ a disintegrin and metallopeptidase 1 a (ADAM1a), ${ }^{111}$ ADAM2,$^{112}$ ADAM3 ${ }^{111,113}$ and calreticulin $3\left(\right.$ CALR3) ${ }^{114}$ are spermatid-specific ER chaperones essential for oviduct migration and sperm-zona pellucida (ZP) binding, as disruption of these genes results in a similar sperm phenotype, that is, impaired migration into the oviduct and ZP-binding ability (Figure 4). Notably, Adam3-null spermatozoa can effectively fertilize eggs when surrounded in cumulus oophorus, suggesting that the principle role of $A D A M 3$ is sperm migration into the oviduct but not ZP binding. ${ }^{115}$

Prss37 deficiency causes the absence of mature ADAM3 in sperm and a defect in sperm migration from the uterus into the oviduct. ${ }^{116}$ Pdilt $^{-1}$ male mice are sterile because ADAM3 could not be folded properly and transported to the sperm surface without the PDILT/CALR3 complex. ${ }^{115,117,118}$ Because ADAM3 is the only protein commonly disrupted or displaced in all of the above-mentioned gene knockout sperm, it is likely that ADAM3 has a central role in sperm migration from the uterus into the oviduct. A recent study suggests that Pmis2-deficient spermatozoa lack the ADAM3 protein, but the amount of PMIS2 is also severely reduced in Adam3-deficient spermatozoa. ${ }^{119}$ Thus the spermatid-specific protein PMIS2 may also function as another ultimately essential factor for sperm migration and/or sperm-ZP binding. Interestingly, in contrast to previously known gene knockout mouse lines, Ly6k-null spermatozoa had no aberrant expression and 


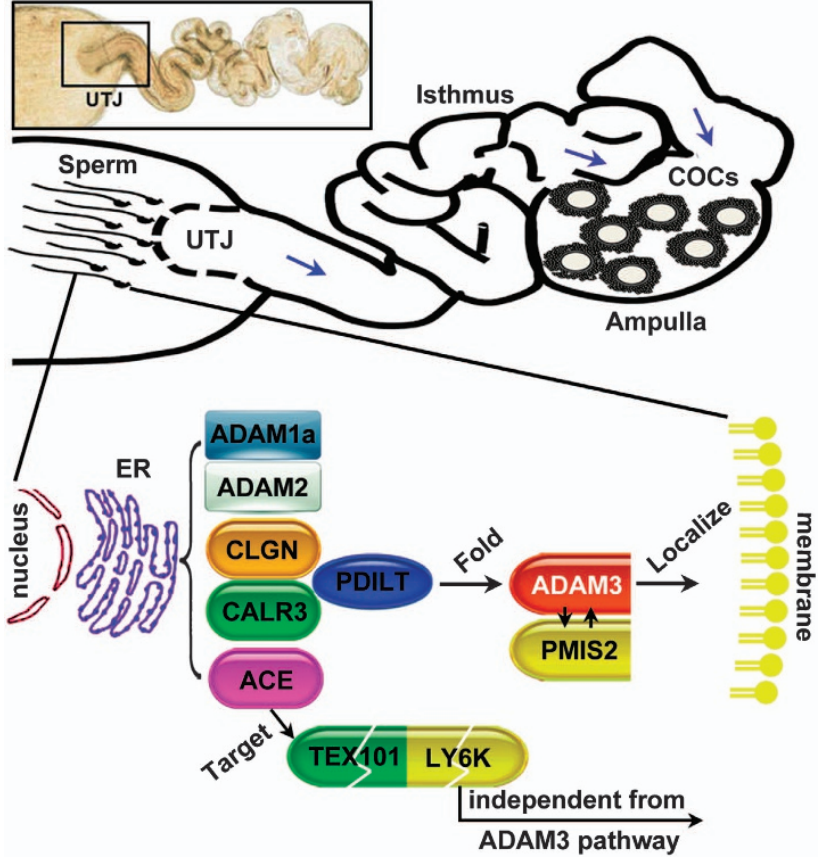

Figure 4 Models for the contributors and roles of the spermatid-specific ER quality-control system. After sperm are deposited in the female reproductive environment, they become metabolically active and pass through the uterotubal junction (UTJ) into the oviduct. ADAM1a, ADAM2, ADAM3, CLGN, CALR3, ACE, PDILT and PMIS2 are spermatid-specific ER chaperones. Disruption of these genes results in similar phenotypes, including impaired migration through the UTJ and/or impaired sperm-ZP binding. Heterodimerization of ADAMs and correct localization of ADAM3 are the central elements for sperm migrating and fertilizing ability. ADAM3 can regulate the PMIS2 expression directly or indirectly. ACE contributes to the removal of TEX101 and LY6K from mature spermatozoa to guarantee correct localization of ADAM3 on the mature sperm surface. Only knockout of $L y 6 k$ does not affect the expression and distribution of ADAM3

distribution of ADAM3. ${ }^{120-122}$ On the other hand, LY6K is present in Clgn, Calr3 and Pdilt mutant mouse lines, suggesting that LY6K may be a novel, ultimately essential, factor independent from the ADAM3 pathway for sperm migrating and/or fertilizing ability.

\section{Spermatid-specific $\mathrm{Na}^{+} / \mathrm{H}^{+}$exchangers (NHEs): spermNHE and NHA1}

NHEs are a family of integral membrane proteins that mediate electroneutral exchange of $\mathrm{Na}^{+}$for $\mathrm{H}^{+}$across the plasma membrane and have important roles in intracellular $\mathrm{pH}(\mathrm{pHi})$ regulation. ${ }^{123,124}$ The SLC9 gene family encodes NHEs and can be divided into three subgroups (reviewed in Martins et $a{ }^{125}{ }^{125}$. Among numerous NHEs, NHE1, ${ }^{126}$ NHE5, ${ }^{127}$ NHE8, ${ }^{128}$ spermNHE ${ }^{129}$ and $\mathrm{NHA1}$ (previously known as mtsNHE) $)^{130}$ are predominantly expressed in the testes. However, normal sperm motility is maintained in $\mathrm{Nhe}^{-1-}$ mice, ${ }^{131}$ suggesting that the Nhe1 gene is independent of male fertility. The role of Nhe5 in sperm motility has yet to be determined. Surprisingly, NHE8 is highly expressed in Leydig cells, and male mice lacking the Nhe8 gene are infertile through its effect on sterol synthesis. ${ }^{128}$
The spermNHE ${ }^{129}$ and $\mathrm{NHA} 1^{130}$ are specifically distributed in the principal piece of the sperm flagellum, and both spermNHE- and Nha1-deficient male mice are completely infertile owing to the severely diminished sperm motility in the female reproductive tracts $^{129,132}$ (Figure 5). The sAC-cAMP signalling is impaired in spermatozoa lacking sperm NHE or Nha1, and the sperm motility defect can be rescued by the addition of cell-permeable CAMP analogues. ${ }^{132,133}$ The sAC is the major source of cAMP in the sperm, and male mice deficient in SAC are infertile because their sperm show no motility despite normal sperm morphology and counts. $^{134}$

We suggest that immunization of female mice with the Nha1/Nha2 (these two Nha genes are functionally redundant) DNA vaccine via oral feeding significantly decreases fertility rate and newborn numbers. ${ }^{132,135}$ The antiserum or vaginal fluid from the Nha1/Nha2 cDNA vaccinated female mice specifically recognized the principal piece of the sperm tail and triggered sperm agglutination. ${ }^{132,135}$ Importantly, principal piece distribution of NHA1 in spermatozoa is phylogenetically conserved in spermatogenesis. ${ }^{132}$ Furthermore, the defect of the Nha1-null sperm is clinically relevant because NHA1 expression is either reduced or absent in patients with teratozoospermia. ${ }^{136}$

\section{$\mathrm{Ca}^{2+} / \mathrm{CaM} /$ kinase in the sperm}

The vigorous asymmetric motion of hyperactivated spermatozoa requires $\mathrm{Ca}^{2+}$ entry into the sperm tail by cation channel of sperm (CatSper), a sperm-specific ion channel. CatSper is directly activated by progesterone and prostaglandins female factors that stimulate $\mathrm{Ca}^{2+}$ influx. ${ }^{137}$ Other factors, including neurotransmitters, chemokines and odorants, also affect sperm function by changing intracellular $\mathrm{Ca}^{2+}$-selective current $\left(I_{\text {CatSper }}\right){ }^{138}$

CatSper1-CatSper4 are highly specialized flagellar proteins, and genetic disruption of any of the four sperm-specific CatSpers abrogated $I_{\text {CatSper, sperm cell hyperactivated }}$ motility and male fertility via disrupting $\mathrm{Ca}^{2+}$ influx ${ }^{139-142}$ (Figure 5). Mutations in CatSper1 and CatSper2 are also associated with male infertility in humans ${ }^{143-145}$; however, CatSper3 and CatSper4 have not been investigated. Each of the CatSper1-CatSper4 genes encodes a subunit of a tetramer surrounding a $\mathrm{Ca}^{2+}$-selective pore-forming a subunit. In addition to the pore-forming proteins, the sperm $\mathrm{Ca}^{2+}$ channel contains the auxiliary subunits CatSper $\beta,{ }^{146}$ CatSper ${ }^{147}$ and CatSper $\delta .{ }^{148}$ Mice lacking the sperm tailspecific CatSper $\delta$ are infertile, and their spermatozoa lack both $\mathrm{Ca}^{2+}$ current and hyperactivated motility. ${ }^{148}$ However, the roles of CatSper $\beta$ and CatSpery and their interactions with other subunits are still unknown.

Downstream of $\mathrm{Ca}^{2+}$, flagellar bending is governed by $\mathrm{Ca}^{2+}$-binding proteins, including CaM, enkurin and calaxin. ${ }^{149}$ $\mathrm{Cris}^{-1-}$ male mice are subfertile owing to altered $\mathrm{Ca}^{2+}$ regulation of flagellar beat asymmetry. ${ }^{150}$ CRIS can directly interact with CaM-activated protein kinase CaMKIV and proteins involved in flagellar transport (e.g., KIF2A, IFT172). ${ }^{150}$ Cnnm4-deficient male mice are almost infertile because of perturbed $\mathrm{Ca}^{2+}$ influx. ${ }^{151}$ 


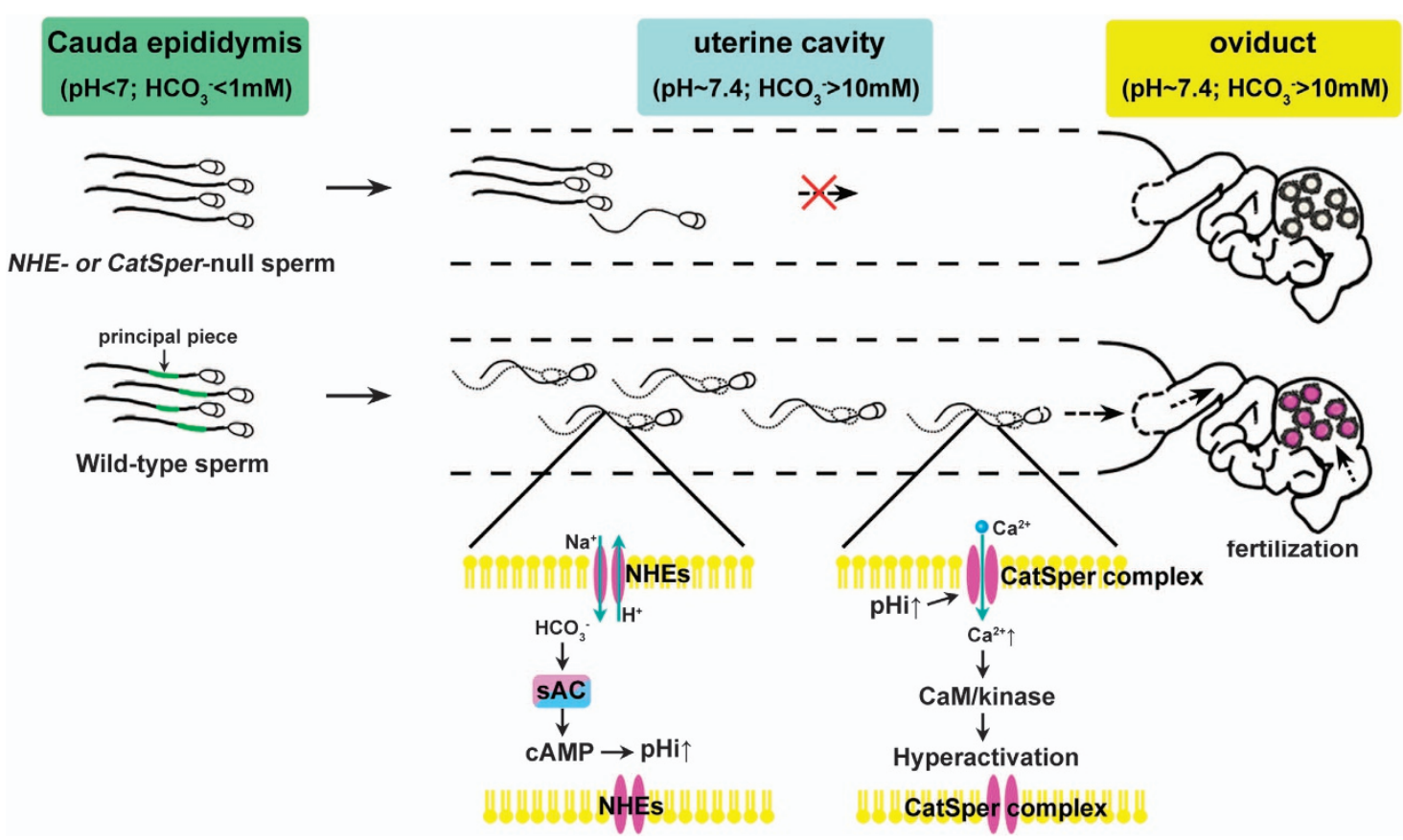

Figure 5 Schematic figure summarizing the critical roles of sperm-specific NHEs and CatSper. Upon ejaculation, sperm stored in the male reproductive tract enter the uterine cavity where they experience a natural decrease of $\mathrm{pH}$ and $\mathrm{HCO}_{3}^{-}$. Normally, sperm adapt quickly to the environment of the female reproductive tract, particularly via $\mathrm{Na}^{+} / \mathrm{H}^{+}$exchangers that are localized to the principal piece of of the sperm flagellum. However, in spermNHE-null and Nha1/2-null mice, sperm show attenuated SAC-CAMP signalling and reduced motility, resulting in failure of movement towards the ampulla of the uterine tubes to fertilize eggs. The increase in $\mathrm{pHi}$ activates a sperm-specific $\mathrm{Ca}^{2+}$ permeable channel complex known as CatSper, which allows an intracellular $\mathrm{Ca}^{2+}$ increase and activation of the $\mathrm{Ca}^{2+} / \mathrm{CaM} /$ kinase signalling pathway essential for hyperactivation

In addition to sperm-specific $\mathrm{Na}^{+} / \mathrm{H}^{+}$exhangers and $\mathrm{pHi}-$ dependent CatSper (reviewed here), there are voltage-gated $\mathrm{H}^{+}$channels, $\mathrm{HCO}_{3}^{-}$transporters and $\mathrm{K}^{+}$channels, which are required for sperm $\mathrm{pHi}$ regulation and sperm motility (refer to Nishigaki et al. ${ }^{152}$ ).

\section{Sperm-specific glycolytic enzyme in adenosine triphosphate (ATP) production}

Glycolysis is the primary source of ATP in sperm. ${ }^{11}$ Targeted disruption of sperm-specific glycolytic enzyme genes, such as Gapdhs, ${ }^{153}$ Ldhc $^{154}{ }^{15 g k 2}{ }^{155}$ and Eno4, ${ }^{156}$ results in reduced levels of ATP in sperm and disruption of sperm motility, leading to male infertility. Recent studies further suggest that Galnt/5deficient mice show male infertility owing to attenuated glycolytic enzymes (e.g., PGK2) required for motility and a patient diagnosed with asthenozoospermia had a mutation in the GALNTL5 gene. ${ }^{157-159}$

\section{Transcriptional regulators of the haploid phase}

Inactivation of Zmynd15 in mice results in early activation of transcription of several haploid genes including Prm1, Tnp1, Spem 1 and Catpser3, as well as depletion of late spermatids and male infertility. ${ }^{160}$ The p.K507Sfs ${ }^{\star} 3$ mutation in exon 9 of ZMYND15 was recently identified in one family with idiopathic azoospermia. ${ }^{161} R f x 2^{-/-}$mice show complete male sterility owing to a complete block in development just prior to spermatid elongation. Many genes (e.g., genes required for flagellum formation and vesicle transport) are directly controlled by RFX2 during spermiogenesis. ${ }^{162,163}$

\section{Perspectives on potential new small-molecule contraceptives targeting spermatogenic-specific proteins}

For the development of non-hormonal male contraceptives, we found that adjudin, an analogue of an anticancer drug called lonidamine, acts by disrupting germ cell-anchoring junctions in the seminiferous epithelium to induce germ cell loss from the testis. ${ }^{164}$ Furthermore, epidydymal protease inhibitor DNA vaccine ${ }^{165}$ and anti-Juno monoclonal antibody ${ }^{166}$ have been developed and tested for male contraception. Recently, spermatogenic-specific proteins (e.g., BRDT, PPP3CC/PPP3R2) have been pursued as potential targets of small-molecule contraceptives ${ }^{167,168}$ (Figure 6).

Bromodomain, testis-specific (BRDT) is a tissue-restricted, chromatin-associated protein expressed in spermatocytes and round spermatids. ${ }^{169}$ BRDT is essential for chromatin remodelling during spermatogenesis and $\mathrm{Brdt}^{-1}$ male mice are sterile, producing fewer and morphologically abnormal elongating sperm. ${ }^{170}$ This information provides a compelling rationale to target BRDT for contraceptive development. Filippakopoulos et al. ${ }^{171}$ have established the feasibility of targeting human BRDT with acetyl-lysine competitive small molecules (JQ1), which blocks the interactions of bromo and extra terminal (BET) proteins (BRD2, BRD3, BRD4 and BRDT) with histones. Subsequently, the complete and 


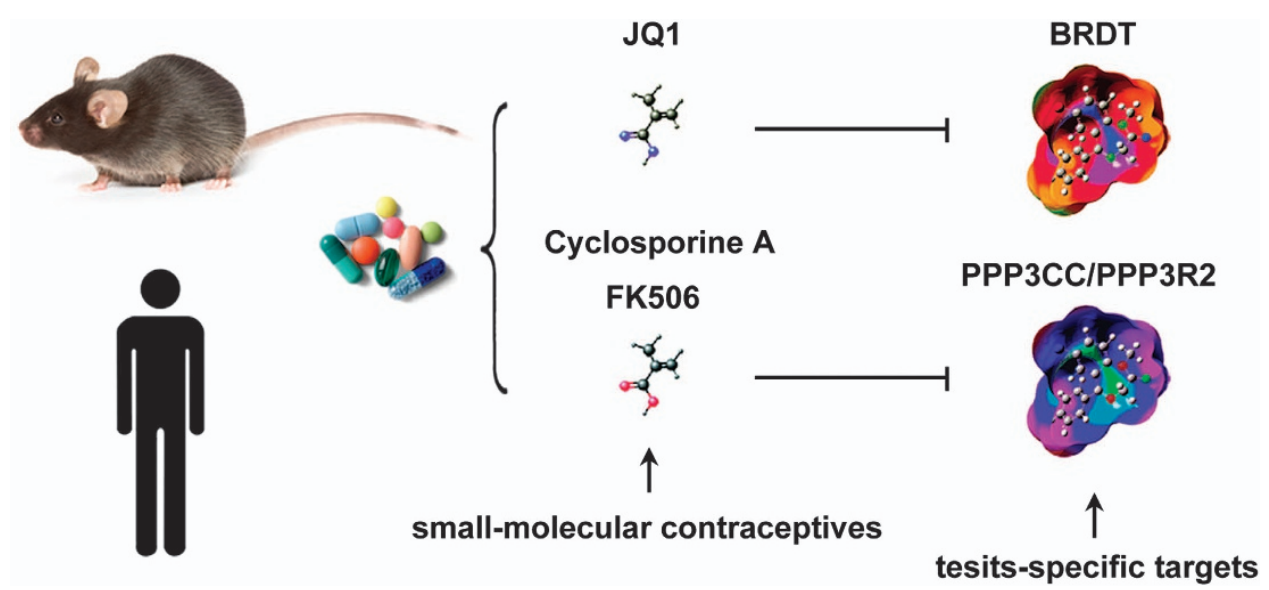

Figure 6 Models for the small-molecule male contraceptives. BRDT is a testis-specific contraceptive target, and JQ1 is a BRDT inhibitor that causes a reversible contraceptive effect in male mice. Sperm-specific calcineurin contains a catalytic subunit (PPP3CC) and a regulatory subunit (PPP3R2). Treatment of mice with calcineurin inhibitors, such as cyclosporine A and FK506, leads to rapid and reversible male infertility. However, side effects need to be taken into consideration

reversible contraceptive effect of JQ1 has been tested in mice. JQ1 treatment reduces testis size, spermatozoa number and motility without affecting hormone levels, including the serum levels of follicle-stimulating hormone, luteinizing hormone and testosterone. ${ }^{167}$ Although JQ1-treated males mate normally, the inhibitory effects of JQ1 evident at the spermatocyte and round spermatid stages cause a complete and reversible contraceptive effect. After JQ1 treatment is halted, the fertility of AQ-treated male mice can be completely returned. ${ }^{167}$

Preliminary studies confirmed that BRDT would meet target specificity, drugability and essential function requirements. However, the clinical and non-clinical safety profile of JQ1 remains to be examined. A recent study argued that mice dosed with JQ1 at efficacious doses exhibit dose-dependent decreases in their lymphoid and immune cell compartments, ${ }^{172}$ illustrating potential issues of immune system interference by JQ1. The development of highly selective small molecules to target BRDT specifically will avoid potential side effects owing to inhibition of its somatic isoforms (e.g., BRD2, BRD3 and BRD4). It is rather remarkable that crystal structure-based virtual screening has recently been used to identify novel potent BRDT inhibitors. ${ }^{173}$

Genetic disruption of either the catalytic subunit (PPP3CC) or the regulatory subunit (PPP3R2) of sperm-specific calcineurin or short-term in vivo pharmacological inhibition with calcineurin inhibitors (cyclosporine A or FK506) leads to complete male infertility, with reduced sperm motility owing to an inflexible midpiece during sperm maturation in the epididymis. ${ }^{168}$ Importantly, inhibitors of sperm-specific calcineurin could act on male fertility both effectively and reversibly because inhibition of PPP3CC/PPP3R2 targets spermatozoa in the epididymis. However, several important considerations remain. Although PPP3CC and PPP3R2 are relatively more abundant in the testis, they are still expressed in other tissues. Furthermore, cyclosporine A or FK506, used as immunosuppressant drugs, can also target the calcineurins present in other cell types. Thus an effective and safe small-molecule inhibitor will need to target only testis-specific calcineurins. ${ }^{174}$
We suggest that targeting spermatid-specific proteins is better, because targeting spermatids is safer and reversibility is less of an issue than targeting spermatocyte- and/or spermatogonia-specific proteins. Many spermatid-specific proteins mentioned in this review (e.g., spermNHE, NHA1, CatSper and GAPDHS) are prime candidates as targets for male contraceptive development using small-molecular inhibitors.

\section{Conclusions and future perspectives}

Studies using mouse knockout technology have identified many spermatid-specific genes essential for spermiogenesis, which in turn are pathogenic factors of human male infertility. The large-scale analysis of mouse models will hopefully help to identify more infertility-related mutations and risk factors in humans. Importantly, the underlying mechanisms and direct correlations between spermiogenic defects of mice and male infertility in humans are far from clear. Rather than investigating novel infertility-associated factors, studies of the classification and inter-relation among known spermatid-specific factors are likely to yield the much needed information.

It is now generally accepted that sperm count and sperm morphplogy/shape are not perfect or reliable indicators of fertility and more assays (e.g., DNA fragmentation analysis, computer-assisted semen analysis, motile sperm organelle morphology examination ${ }^{175}$ and gene mutation screening) need to be adapted for clinical use. ${ }^{176}$ Some obvious structural defects can be detected microscopically, whereas some defects in energy production, signalling transduction and metabolism require more sophisticated assays for screening. Although the molecular diagnosis of infertility would be difficult with the current available technologies, we suggest that deletions and/or mutations in SPATA16, ${ }^{36,37}$ PICK $1{ }^{38}$ DPY19L2, ${ }^{39}$ ZPBP1, ${ }^{40}$ DNAH1, ${ }^{41}$ CatSper1/2, ${ }^{143,144,145}$ GALNTL5 $5^{158}$ and others ${ }^{7}$ need to be checked for infertility diagnosis of globozoospermia. Whole genome-based techniques will hopefully help to identify more infertility-related mutations and risk factors in future. 
A male contraceptive 'pill' is still many years away. But recent research into developing small-molecule inhibitors that target specific sperm antigens/enzymes/proteins as contraceptives may offer some insightful information in male contraceptive development.

\section{Conflict of Interest}

The authors declare no conflict of interest.

Acknowledgements. This up-to-date review refers to many outstanding research papers and reviews. We apologize to colleagues whose work is not cited here owing to limited space or our unintentional negligence. This work was supported by Major Research Plan '973' Project (2012CB944702), Natural Science Foundation of China (31171380, 31471352, 31501198 and 81270662) and Academician Workstation Support (Shenyang, Changsha and Shandong).

\section{Author contributions}

Su-Ren Chen and Yi-Xun Liu were involved in conception and designing, drafting and revising the article. Aalia Batool, Yu-Qian Wang and Xiao-Xia Hao contributed to the literature collection. Chawn-Shang Chang and $\mathrm{C}$ Yan Cheng gave critical revision of the manuscript. All authors read and approved the final manuscript.

1. Skakkebaek NE, Jorgensen N, Main KM, Rajpert-De Meyts E, Leffers $H$, Andersson AM et al. Is human fecundity declining? Int J Androl 2006; 29: 2-11.

2. Ombelet W, Cooke I, Dyer S, Serour G, Devroey P. Infertility and the provision of infertility medical services in developing countries. Hum Reprod Update 2008; 14: 605-621.

3. Liu PY, Handelsman DJ. The present and future state of hormonal treatment for male infertility. Hum Reprod Update 2003; 9: 9-23.

4. Georgiou I, Syrrou M, Pardalidis N, Karakitsios K, Mantzavinos T, Giotitsas N et al. Genetic and epigenetic risks of intracytoplasmic sperm injection method. Asian J Androl 2006; 8: 643-673.

5. O'Flynn O'Brien $\mathrm{KL}$, Varghese AC, Agarwal A. The genetic causes of male factor infertility: a review. Fertil Steril 2010; 93: 1-12.

6. Yuen RK, Merkoulovitch A, MacDonald JR, Vlasschaert M, Lo K, Grober E et al. Development of a high-resolution Y-chromosome microarray for improved male infertility diagnosis. Fertil Steril 2014; 101: 1079.e3-1085.e3.

7. Massart A, Lissens W, Tournaye H, Stouffs K. Genetic causes of spermatogenic failure Asian J Androl 2012; 14: 40-48.

8. Liu YX. Control of spermatogenesis in primate and prospect of male contraception. Arch Androl 2005; 51: 77-92

9. Hermo L, Pelletier RM, Cyr DG, Smith CE. Surfing the wave, cycle, life history, and genes/ proteins expressed by testicular germ cells. Part 1: background to spermatogenesis, spermatogonia, and spermatocytes. Microsc Res Tech 2010; 73: 241-278.

10. Chen SR, Liu YX. Regulation of spermatogonial stem cell self-renewal and spermatocyte meiosis by Sertoli cell signaling. Reproduction 2015; 149: R159-R167.

11. Yan W. Male infertility caused by spermiogenic defects: lessons from gene knockouts. Mol Cell Endocrinol 2009; 306: 24-32.

12. Friedel RH, Wurst W, Wefers B, Kuhn R. Generating conditional knockout mice. Methods Mol Biol 2011; 693: 205-231.

13. Kennedy $\mathrm{CL}$, O'Bryan MK. N-ethyl-N-nitrosourea (ENU) mutagenesis and male fertility research. Hum Reprod Update 2006; 12: 293-301.

14. Moreno RD, Ramalho-Santos J, Sutovsky P, Chan EK, Schatten G. Vesicular traffic and golgi apparatus dynamics during mammalian spermatogenesis: implications for acrosome architecture. Biol Reprod 2000; 63: 89-98.

15. Abou-Haila A, Tulsiani DR. Mammalian sperm acrosome: formation, contents, and function. Arch Biochem Biophys 2000; 379: 173-182.

16. Perrin A, Coat C, Nguyen MH, Talagas M, Morel F, Amice J et al. Molecular cytogenetic and genetic aspects of globozoospermia: a review. Andrologia 2013; 45: 1-9.

17. Dam AH, Feenstra I, Westphal JR, Ramos L, van Golde RJ, Kremer JA. Globozoospermia revisited. Hum Reprod Update 2007; 13: 63-75.

18. Pierre V, Martinez G, Coutton C, Delaroche J, Yassine S, Novella C et al. Absence of Dpy1912, a new inner nuclear membrane protein, causes globozoospermia in mice by preventing the anchoring of the acrosome to the nucleus. Development 2012; 139: 2955-2965.

19. Xiao N, Kam C, Shen C, Jin W, Wang J, Lee KM et al. PICK1 deficiency causes male infertility in mice by disrupting acrosome formation. J Clin Invest 2009; 119: 802-812.

20. Neesen J, Kirschner R, Ochs M, Schmiedl A, Habermann B, Mueller C et al. Disruption of an inner arm dynein heavy chain gene results in asthenozoospermia and reduced ciliary beat frequency. Hum Mol Genet 2001; 10: 1117-1128.

21. Yao R, Ito C, Natsume $Y$, Sugitani $Y$, Yamanaka $H$, Kuretake $S$ et al. Lack of acrosome formation in mice lacking a Golgi protein, GOPC. Proc Natl Acad Sci USA 2002; 99: $11211-11216$
22. Paiardi C, Pasini ME, Gioria M, Berruti G. Failure of acrosome formation and globozoospermia in the wobbler mouse, a Vps54 spontaneous recessive mutant Spermatogenesis 2011; 1: 52-62.

23. Kang-Decker N, Mantchev GT, Juneja SC, McNiven MA, van Deursen JM. Lack of acrosome formation in Hrb-deficient mice. Science 2001; 294: 1531-1533.

24. Lin YN, Roy A, Yan W, Burns KH, Matzuk MM. Loss of zona pellucida binding proteins in the acrosomal matrix disrupts acrosome biogenesis and sperm morphogenesis. Mol Cell Biol 2007; 27: 6794-6805.

25. Xu X, Toselli PA, Russell LD, Seldin DC. Globozoospermia in mice lacking the casein kinase II alpha' catalytic subunit. Nat Genet 1999; 23: 118-121.

26. Audouard C, Christians E. Hsp90beta1 knockout targeted to male germline: a mouse model for globozoospermia. Fertil Steril 2011; 95: 1475-1477 e1471-1474.

27. Yildiz Y, Matern H, Thompson B, Allegood JC, Warren RL, Ramirez DM et al. Mutation of beta-glucosidase 2 causes glycolipid storage disease and impaired male fertility. $J$ Clin Invest 2006; 116: 2985-2994

28. Fujihara $Y$, Satouh $Y$, Inoue N, Isotani A, Ikawa M, Okabe M. SPACA1-deficient male mice are infertile with abnormally shaped sperm heads reminiscent of globozoospermia Development 2012; 139: 3583-3589.

29. Wang $\mathrm{H}$, Wan $\mathrm{H}$, Li X, Liu W, Chen $\mathrm{Q}$, Wang $\mathrm{Y}$ et al. Atg7 is required for acrosome biogenesis during spermatogenesis in mice. Cell Res 2014; 24: 852-869.

30. Funaki T, Kon S, Tanabe K, Natsume W, Sato S, Shimizu T et al. The Arf GAP SMAP2 is necessary for organized vesicle budding from the trans-Golgi network and subsequen acrosome formation in spermiogenesis. Mol Biol Cell 2013; 24: 2633-2644.

31. Roqueta-Rivera M, Abbott TL, Sivaguru M, Hess RA, Nakamura MT. Deficiency in the omega-3 fatty acid pathway results in failure of acrosome biogenesis in mice. Biol Reprod 2011; 85: 721-732.

32. Wu $Y$, Chen $X$, Wang $S$, Jiang $M$, Zheng $B$, Zhou $Q$ et al. Flotillin-2 is an acrosome-related protein involved in mouse spermiogenesis. J Biomed Res 2012; 26: 278-287.

33. Geng Q, Ni L, Ouyang B, Hu Y, Zhao Y, Guo J. A novel testis-specific gene, Ccdc136 is required for acrosome formation and fertilization in mice. Reprod Sci 2016; 23 1387-1396.

34. Tardif S, Guyonnet B, Cormier N, Cornwall GA. Alteration in the processing of the ACRBP sp32 protein and sperm head/acrosome malformations in proprotein convertase 4 (PCSK4) null mice. Mol Hum Reprod 2012; 18: 298-307.

35. Doran J, Walters C, Kyle V, Wooding P, Hammett-Burke R, Colledge WH. Mfsd14a (Hiat1) gene disruption causes globozoospermia and infertility in male mice. Reproduction 2016; 152: 91-99.

36. Dam AH, Koscinski I, Kremer JA, Moutou C, Jaeger AS, Oudakker AR et al. Homozygous mutation in SPATA16 is associated with male infertility in human globozoospermia. Am J Hum Genet 2007; 81: 813-820.

37. Ellnati E, Fossard C, Okutman O, Ghedir H, Ibala-Romdhane S, Ray PF et al. A new mutation identified in SPATA16 in two globozoospermic patients. $J$ Assist Reprod Genet 2016; 33: 815-820.

38. Liu G, Shi QW, Lu GX. A newly discovered mutation in PICK1 in a human with globozoospermia. Asian J Androl 2010; 12: 556-560.

39. Harbuz R, Zouari R, Pierre V, Ben Khelifa M, Kharouf M, Coutton C et al. A recurren deletion of DPY19L2 causes infertility in man by blocking sperm head elongation and acrosome formation. Am J Hum Genet 2011; 88: 351-361.

40. Yatsenko AN, O'Neil DS, Roy A, Arias-Mendoza PA, Chen R, Murthy LJ et al. Association of mutations in the zona pellucida binding protein 1 (ZPBP1) gene with abnormal sperm head morphology in infertile men. Mol Hum Reprod 2012; 18: 14-21.

41. Ben Khelifa M, Coutton C, Zouari R, Karaouzene T, Rendu J, Bidart M et al. Mutations in DNAH1, which encodes an inner arm heavy chain dynein, lead to male infertility from multiple morphological abnormalities of the sperm flagella. Am J Hum Genet 2014; 94: 95-104.

42. Kanemori Y, Koga Y, Sudo M, Kang W, Kashiwabara SI, Ikawa M et al. Biogenesis of sperm acrosome is regulated by pre-mRNA alternative splicing of Acrbp in the mouse. Proc Natl Acad Sci USA 2016; 113: 3696-3705.

43. He J, Xia M, Tsang WH, Chow KL, Xia J. ICA1L forms BAR-domain complexes with PICK1 and is crucial for acrosome formation in spermiogenesis. J Cell Sci 2015; 128: 3822-3836.

44. Buffone MG, Hirohashi N, Gerton GL. Unresolved questions concerning mammalian sperm acrosomal exocytosis. Biol Reprod 2014; 90: 112.

45. Okabe M. The acrosome reaction: a historical perspective. Adv Anat Embryol Cell Biol 2016; 220: 1-13.

46. Li YC, Hu XQ, Zhang KY, Guo J, Hu ZY, Tao SX et al. Afaf, a novel vesicle membrane protein, is related to acrosome formation in murine testis. FEBS Lett 2006: 580: 4266-4273.

47. Ito C, Yamatoya K, Yoshida K, Fujimura L, Hatano M, Miyado K et al. Integration of the mouse sperm fertilization-related protein equatorin into the acrosome during spermatogenesis as revealed by super-resolution and immunoelectron microscopy. Cell Tissue Res 2013; 352: 739-750.

48. Fujihara $Y$, Murakami M, Inoue N, Satouh $Y$, Kaseda K, Ikawa M et al. Sperm equatoria segment protein 1, SPESP1, is required for fully fertile sperm in mouse. J Cell Sci 2010; 123(Pt 9): 1531-1536

49. Wolkowicz MJ, Digilio L, Klotz K, Shetty J, Flickinger CJ, Herr JC. Equatorial segment protein (ESP) is a human alloantigen involved in sperm-egg binding and fusion. $J$ Androl 2008; 29: 272-282. 
50. Suryavathi V, Panneerdoss S, Wolkowicz MJ, Shetty J, Sherman NE, Flickinger CJ et al. Dynamic changes in equatorial segment protein 1 (SPESP1) glycosylation during mouse spermiogenesis. Biol Reprod 2015; 92: 129.

51. Hu XQ, Ji SY, Li YC, Fan CH, Cai H, Yang JL et al. Acrosome formation-associated factor is involved in fertilization. Fertil Steril 2010; 93: 1482-1492.

52. Hao J, Chen M, Ji S, Wang X, Wang Y, Huang $X$ et al. Equatorin is not essential for acrosome biogenesis but is required for the acrosome reaction. Biochem Biophys Res Commun 2014; 444: 537-542.

53. Kierszenbaum AL. Intramanchette transport (IMT): managing the making of the spermatid head, centrosome, and tail. Mol Reprod Dev 2002; 63: 1-4.

54. Lehti MS, Sironen A. Formation and function of the manchette and flagellum during spermatogenesis. Reproduction 2016; 151: R43-R54.

55. Zhou J, Yang F, Leu NA, Wang PJ. MNS1 is essential for spermiogenesis and motile ciliary functions in mice. PLoS Genet 2012; 8: e1002516.

56. Lehti MS, Kotaja N, Sironen A. KIF3A is essential for sperm tail formation and manchette function. Mol Cell Endocrinol 2013; 377: 44-55.

57. Lehti MS, Kotaja N, Sironen A. KIF1-binding protein interacts with KIF3A in haploid male germ cells. Reproduction 2015; 150: 209-216.

58. Zhou J, Du YR, Qin WH, Hu YG, Huang YN, Bao L et al. RIM-BP3 is a manchetteassociated protein essential for spermiogenesis. Development 2009; 136: 373-382.

59. Kramer H, Phistry M. Genetic analysis of hook, a gene required for endocytic trafficking in drosophila. Genetics 1999; 151: 675-684.

60. Mendoza-Lujambio I, Burfeind P, Dixkens C, Meinhardt A, Hoyer-Fender S, Engel W et al The Hook1 gene is non-functional in the abnormal spermatozoon head shape (azh) mutant mouse. Hum Mol Genet 2002; 11: 1647-1658.

61. Zhang Z, Shen X, Gude DR, Wilkinson BM, Justice MJ, Flickinger CJ et al. MEIG1 is essential for spermiogenesis in mice. Proc Natl Acad Sci USA 2009; 106: 17055-17060.

62. Zhang L, Shang XJ, Li HF, Shi YQ, Li W, Teves ME et al. Characterization of membrane occupation and recognition nexus repeat containing 3 , meiosis expressed gene 1 binding partner, in mouse male germ cells. Asian J Androl 2015; 17: 86-93.

63. Liu Y, DeBoer K, de Kretser DM, O'Donnell L, O'Connor AE, Merriner DJ et al. LRGUK-1 is required for basal body and manchette function during spermatogenesis and male fertility. PLOS Genet 2015; 11: e1005090.

64. Baron Gaillard CL, Pallesi-Pocachard E, Massey-Harroche D, Richard F, Arsanto JP, Chauvin JP et al. Hook2 is involved in the morphogenesis of the primary cilium. Mol Biol Cell 2011; 22: 4549-4562.

65. Pasch E, Link J, Beck C, Scheuerle S, Alsheimer M. The LINC complex component Sun4 plays a crucial role in sperm head formation and fertility. Biol Open 2015; 4: 1792-1802.

66. Calvi A, Wong AS, Wright G, Wong ES, Loo TH, Stewart CL et al. SUN4 is essential for nuclear remodeling during mammalian spermiogenesis. Dev Biol 2015; 407: 321-330.

67. Hall EA, Keighren M, Ford MJ, Davey T, Jarman AP, Smith LB et al. Acute versus chronic loss of mammalian Azi1/Cep131 results in distinct ciliary phenotypes. PLoS Genet 2013; 9 e1003928.

68. Zheng H, Stratton CJ, Morozumi K, Jin J, Yanagimachi R, Yan W. Lack of Spem1 causes aberrant cytoplasm removal, sperm deformation, and male infertility. Proc Natl Acad Sci USA 2007; 104: 6852-6857.

69. Bao J, Zhang J, Zheng H, Xu C, Yan W. UBQLN1 interacts with SPEM1 and participates in spermiogenesis. Mol Cell Endocrinol 2010; 327: 89-97.

70. Bao J, Wu Q, Song R, Jie Z, Zheng H, Xu C et al. RANBP17 is localized to the XY body of spermatocytes and interacts with SPEM1 on the manchette of elongating spermatids. Mol Cell Endocrinol 2011; 333: 134-142.

71. Nozawa YI, Yao E, Gacayan R, Xu SM, Chuang PT. Mammalian Fused is essential for sperm head shaping and periaxonemal structure formation during spermatogenesis. Dev Biol 2014; 388: 170-180.

72. Yamaguchi N, Takanezawa Y, Koizumi H, Umezu-Goto M, Aoki J, Arai H. Expression of NUDEL in manchette and its implication in spermatogenesis. FEBS Lett 2004; 566: 71-76.

73. Akhmanova A, Mausset-Bonnefont AL, van Cappellen W, Keijzer N, Hoogenraad CC, Stepanova T et al. The microtubule plus-end-tracking protein CLIP-170 associates with the spermatid manchette and is essential for spermatogenesis. Genes Dev 2005; 19: 2501-2515.

74. O'Donnell L, McLachlan RI, Merriner DJ, O'Bryan MK, Jamsai D. KATNB1 in the human testis and its genetic variants in fertile and oligoasthenoteratozoospermic infertile men. Andrology 2014; 2: 884-891.

75. Qi Y, Jiang M, Yuan Y, Bi Y, Zheng B, Guo X et al. ADP-ribosylation factor-like 3, a manchette-associated protein, is essential for mouse spermiogenesis. Mol Hum Reprod 2013; 19: 327-335.

76. Harris TP, Schimenti KJ, Munroe RJ, Schimenti JC. IQ motif-containing G (lqcg) is required for mouse spermiogenesis. G3 2014; 4: 367-372.

77. Woolley DM. Flagellar oscillation: a commentary on proposed mechanisms. Biol Rev Camb Philos Soc 2010; 85: 453-470.

78. Fawcett DW, Phillips DM. The fine structure and development of the neck region of the mammalian spermatozoon. Anat Rec 1969; 165: 153-164.

79. Kamal A, Mansour R, Fahmy I, Serour G, Rhodes C, Aboulghar M. Easily decapitated spermatozoa defect: a possible cause of unexplained infertility. Hum Reprod 1999; 14 2791-2795.

80. Panidis D, Rousso D, Kourtis A, Gianoulis C, Papathanasiou K, Kalachanis J. Headless spermatozoa in semen specimens from fertile and subfertile men. J Reprod Med 2001; 46: 947-950.
81. Moretti E, Geminiani M, Terzuoli G, Renieri T, Pascarelli N, Collodel G. Two cases of sperm immotility: a mosaic of flagellar alterations related to dysplasia of the fibrous sheath and abnormalities of head-neck attachment. Fertil Steril 2011; 95: 1787.e19-1787.e23.

82. Tosaka Y, Tanaka H, Yano Y, Masai K, Nozaki M, Yomogida $\mathrm{K}$ et al. Identification and characterization of testis specific ornithine decarboxylase antizyme (OAZ-t) gene: expression in haploid germ cells and polyamine-induced frameshifting. Genes Cells 2000; 5: 265-276.

83. Tokuhiro $\mathrm{K}$, Isotani A, Yokota S, Yano Y, Oshio S, Hirose M et al. OAZ-t/OAZ3 is essential for rigid connection of sperm tails to heads in mouse. PLoS Genet 2009; 5: e1000712.

84. Ruan Y, Cheng M, Ou Y, Oko R, van der Hoorn FA. Ornithine decarboxylase antizyme Oaz3 modulates protein phosphatase activity. J Biol Chem 2011; 286: 29417-29427.

85. Yang K, Meinhardt A, Zhang B, Grzmil P, Adham IM, Hoyer-Fender S. The small heat shock protein ODF1/HSPB10 is essential for tight linkage of sperm head to tail and male fertility in mice. Mol Cell Biol 2012; 32: 216-225.

86. Yang K, Grzmil P, Meinhardt A, Hoyer-Fender S. Haplo-deficiency of ODF1/HSPB10 in mouse sperm causes relaxation of head-to-tail linkage. Reproduction 2014; 148: 499-506.

87. Oh C, Aho H, Shamsadin R, Nayernia K, Muller C, Sancken U et al. Characterization, expression pattern and chromosomal localization of the spermatogenesis associated 6 gene (Spata6). Mol Hum Reprod 2003; 9: 321-330.

88. Yuan S, Stratton CJ, Bao J, Zheng H, Bhetwal BP, Yanagimachi R et al. Spata6 is required for normal assembly of the sperm connecting piece and tight head-tail conjunction. Proc Natl Acad Sci USA 2015; 112: E430-E439.

89. Toure A, Rode B, Hunnicutt GR, Escalier D, Gacon G. Septins at the annulus of mammalian sperm. Biol Chem 2011; 392: 799-803.

90. Ihara M, Kinoshita A, Yamada S, Tanaka H, Tanigaki A, Kitano A et al. Cortical organization by the septin cytoskeleton is essential for structural and mechanical integrity of mammalian spermatozoa. Dev Cell 2005; 8: 343-352.

91. Sugino Y, Ichioka K, Soda T, Ihara M, Kinoshita M, Ogawa O et al. Septins as diagnostic markers for a subset of human asthenozoospermia. J Urol 2008; 180: 2706-2709.

92. Kuo YC, Lin YH, Chen HI, Wang YY, Chiou YW, Lin HH et al. SEPT12 mutations cause male infertility with defective sperm annulus. Hum Mutat 2012; 33: 710-719.

93. Kissel H, Georgescu MM, Larisch S, Manova K, Hunnicutt GR, Steller H. The Sept4 septin locus is required for sperm terminal differentiation in mice. Dev Cell 2005; 8: 353-364.

94. Kuo YC, Shen YR, Chen HI, Lin YH, Wang YY, Chen YR et al. SEPT12 orchestrates the formation of mammalian sperm annulus by organizing core octameric complexes with other SEPT proteins. J Cell Sci 2015; 128: 923-934.

95. Guan J, Kinoshita M, Yuan L. Spatiotemporal association of DNAJB13 with the annulus during mouse sperm flagellum development. BMC Dev Biol 2009; 9: 23.

96. Yeh CH, Kuo PL, Wang YY, Wu YY, Chen MF, Lin DY et al. SEPT12/SPAG4/LAMINB1 complexes are required for maintaining the integrity of the nuclear envelope in postmeiotic male germ cells. PLoS One 2015; 10: e0120722.

97. Li Y, Sosnik J, Brassard L, Reese M, Spiridonov NA, Bates TC et al. Expression and localization of five members of the testis-specific serine kinase (Tssk) family in mouse and human sperm and testis. Mol Hum Reprod 2011; 17: 42-56.

98. Wang X, Wei Y, Fu G, Li H, Saiyin H, Lin G et al. Tssk4 is essential for maintaining the structural integrity of sperm flagellum. Mol Hum Reprod 2015; 21: 136-145.

99. Olson GE, Winfrey VP, Nagdas SK, Hill KE, Burk RF. Selenoprotein P is required for mouse sperm development. Biol Reprod 2005; 73: 201-211.

100. Toure A, Lhuillier $P$, Gossen JA, Kuil CW, Lhote D, Jegou B et al. The testis anion transporter 1 (Slc26a8) is required for sperm terminal differentiation and male fertility in the mouse. Hum Mol Genet 2007; 16: 1783-1793.

101. Lhuillier P, Rode B, Escalier D, Lores P, Dirami T, Bienvenu T et al. Absence of annulus in human asthenozoospermia: case report. Hum Reprod 2009; 24: 1296-1303.

102. Lim S, Kaldis P. Cdks, cyclins and CKIs: roles beyond cell cycle regulation. Development 2013; 140: 3079-3093.

103. Wolgemuth DJ, Manterola M, Vasileva A. Role of cyclins in controlling progression of mammalian spermatogenesis. Int J Dev Biol 2013; 57: 159-168.

104. Mikolcevic P, Sigl R, Rauch V, Hess MW, Pfaller K, Barisic M et al. Cyclin-dependent kinase 16/PCTAIRE kinase 1 is activated by cyclin Yand is essential for spermatogenesis. Mol Cell Biol 2012; 32: 868-879.

105. Zi Z, Zhang Z, Li Q, An W, Zeng L, Gao D et al. CCNYL1, but not CCNY, cooperates with CDK16 to regulate spermatogenesis in mouse. PLOS Genet 2015; 11: e1005485.

106. Koch S, Acebron SP, Herbst J, Hatiboglu G, Niehrs C. Post-transcriptional Wnt signaling governs epididymal sperm maturation. Cell 2015; 163: 1225-1236.

107. Ellgaard L, Helenius A. Quality control in the endoplasmic reticulum. Nat Rev Mol Cell Biol 2003; 4: 181-191.

108. Trombetta ES, Parodi AJ. Quality control and protein folding in the secretory pathway. Annu Rev Cell Dev Biol 2003; 19: 649-676.

109. Ikawa M, Nakanishi T, Yamada S, Wada I, Kominami K, Tanaka $\mathrm{H}$ et al. Calmegin is required for fertilin alpha/beta heterodimerization and sperm fertility. Dev Biol 2001; 240: 254-261.

110. Yamaguchi R, Yamagata K, Ikawa M, Moss SB, Okabe M. Aberrant distribution of ADAM3 in sperm from both angiotensin-converting enzyme (Ace)- and calmegin (Clgn)deficient mice. Biol Reprod 2006; 75: 760-766.

111. Nishimura $\mathrm{H}, \mathrm{Kim} \mathrm{E}$, Nakanishi T, Baba T. Possible function of the ADAM1a/ADAM2 Fertilin complex in the appearance of ADAM3 on the sperm surface. J Biol Chem 2004; 279: 34957-34962 
112. Cho $C$, Bunch DO, Faure JE, Goulding EH, Eddy EM, Primakoff $P$ et al. Fertilization defects in sperm from mice lacking fertilin beta. Science 1998; 281: 1857-1859.

113. Yamaguchi R, Muro Y, Isotani A, Tokuhiro K, Takumi K, Adham I et al. Disruption of ADAM3 impairs the migration of sperm into oviduct in mouse. Biol Reprod 2009; 81: 142-146.

114. Ikawa M, Tokuhiro K, Yamaguchi R, Benham AM, Tamura T, Wada I et al. Calsperin is a testis-specific chaperone required for sperm fertility. J Biol Chem 2011; 286: 5639-5646.

115. Tokuhiro K, Ikawa M, Benham AM, Okabe M. Protein disulfide isomerase homolog PDILT is required for quality control of sperm membrane protein ADAM3 and male fertility [corrected]. Proc Natl Acad Sci USA 2012; 109: 3850-3855.

116. Shen $\mathrm{C}$, Kuang $\mathrm{Y}$, Liu J, Feng J, Chen $\mathrm{X}$, Wu W et al. Prss 37 is required for male fertility in the mouse. Biol Reprod 2013; 88: 123.

117. van Lith M, Hartigan N, Hatch J, Benham AM. PDILT, a divergent testis-specific protein disulfide isomerase with a non-classical SXXC motif that engages in disulfide-dependent interactions in the endoplasmic reticulum. J Biol Chem 2005; 280: 1376-1383.

118. van Lith M, Karala AR, Bown D, Gatehouse JA, Ruddock LW, Saunders PT et al. A developmentally regulated chaperone complex for the endoplasmic reticulum of male haploid germ cells. Mol Biol Cell 2007; 18: 2795-2804.

119. Yamaguchi R, Fujihara $Y$, Ikawa M, Okabe M. Mice expressing aberrant sperm-specific protein PMIS2 produce normal-looking but fertilization-incompetent spermatozoa. Mol Biol Cell 2012; 23: 2671-2679

120. Endo S, Yoshitake H, Tsukamoto H, Matsuura H, Kato K, Sakuraba M et al. TEX101, a glycoprotein essential for sperm fertility, is required for stable expression of Ly6k on testicular germ cells. Sci Rep 2016; 6: 23616.

121. Fujihara Y, Tokuhiro K, Muro Y, Kondoh G, Araki Y, Ikawa M et al. Expression of TEX101, regulated by ACE, is essential for the production of fertile mouse spermatozoa. Proc Natl Acad Sci USA 2013; 110: 8111-8116.

122. Fujihara Y, Okabe M, Ikawa M. GPI-anchored protein complex, LY6K/TEX101, is required for sperm migration into the oviduct and male fertility in mice. Biol Reprod 2014; 90: 60.

123. Donowitz M, Cha B, Zachos NC, Brett CL, Sharma A, Tse CM et al. NHERF family and NHE3 regulation. J Physiol 2005; 567(Pt 1): 3-11.

124. Garcia MA, Meizel S. Regulation of intracellular pH in capacitated human spermatozoa by a $\mathrm{Na}+/ \mathrm{H}+$ exchanger. Mol Reprod Dev 1999; 52: 189-195.

125. Martins AD, Bernardino RL, Neuhaus-Oliveira A, Sousa M, Sa R, Alves MG et al. Physiology of na+ $/ h+$ exchangers in the male reproductive tract: relevance for male fertility. Biol Reprod 2014; 91: 11.

126. Woo AL, James PF, Lingrel JB. Roles of the Na,K-ATPase alpha4 isoform and the $\mathrm{Na}+/ \mathrm{H}+$ exchanger in sperm motility. Mol Reprod Dev 2002; 62: 348-356.

127. Klanke CA, Su YR, Callen DF, Wang Z, Meneton P, Baird N et al. Molecular cloning and physical and genetic mapping of a novel human $\mathrm{Na}+/ \mathrm{H}+$ exchanger (NHE5/SLC9A5) to chromosome 16q22.1. Genomics 1995; 25: 615-622.

128. Xu H, Chen H, Li J, Zhao Y, Ghishan FK. Disruption of NHE8 expression impairs Leydig cell function in the testes. Am J Physiol Cell Physiol 2015; 308: C330-C338.

129. Wang D, King SM, Quill TA, Doolittle LK, Garbers DL. A new sperm-specific $\mathrm{Na}+/ \mathrm{H}+$ exchanger required for sperm motility and fertility. Nat Cell Biol 2003; 5 : 1117-1122.

130. Liu T, Huang JC, Zuo WL, Lu CL, Chen M, Zhang XS et al. A novel testis-specific $\mathrm{Na}+/ \mathrm{H}+$ exchanger is involved in sperm motility and fertility. Front Biosci 2010; 2 : 566-581.

131. Bell SM, Schreiner CM, Schultheis PJ, Miller ML, Evans RL, Vorhees CV et al. Targeted disruption of the murine Nhe1 locus induces ataxia, growth retardation, and seizures. Am J Physiol 1999; 276(Pt 1): C788-C795.

132. Chen SR, Chen M, Deng SL, Hao XX, Wang XX, Liu YX. Sodium-hydrogen exchanger NHA1 and NHA2 control sperm motility and male fertility. Cell Death Dis 2016; 7: e2152.

133. Wang D, Hu J, Bobulescu IA, Quill TA, McLeroy P, Moe OW et al. A sperm-specific Na+/H+ exchanger (SNHE) is critical for expression and in vivo bicarbonate regulation of the soluble adenylyl cyclase (sAC). Proc Natl Acad Sci USA 2007; 104: 9325-9330.

134. Esposito G, Jaiswal BS, Xie F, Krajnc-Franken MA, Robben TJ, Strik AM et al. Mice deficient for soluble adenylyl cyclase are infertile because of a severe sperm-motility defect. Proc Natl Acad Sci USA 2004; 101: 2993-2998.

135. Liu T, Huang JC, Lu CL, Yang JL, Hu ZY, Gao F et al. Immunization with a DNA vaccine of testis-specific sodium-hydrogen exchanger by oral feeding or nasal instillation reduces fertility in female mice. Fertil Steril 2010; 93: 1556-1566.

136. Kumar PL, James PF. Identification and characterization of methylation-dependent/ independent DNA regulatory elements in the human SLC9B1 gene. Gene 2015; 561: 235-248

137. Lishko PV, Botchkina IL, Kirichok Y. Progesterone activates the principal Ca2+ channel of human sperm. Nature 2011; 471: 387-391.

138. Brenker C, Goodwin N, Weyand I, Kashikar ND, Naruse M, Krahling M et al. The CatSper channel: a polymodal chemosensor in human sperm. EMBO J 2012; 31: 1654-1665.

139. Ren D, Navarro B, Perez G, Jackson AC, Hsu S, Shi $Q$ et al. A sperm ion channel required for sperm motility and male fertility. Nature 2001; 413: 603-609.

140. Carlson AE, Westenbroek RE, Quill T, Ren D, Clapham DE, Hille B et al. CatSper1 required for evoked Ca2+ entry and control of flagellar function in sperm. Proc Natl Acad Sci USA 2003; 100: 14864-14868.

141. Quill TA, Sugden SA, Rossi KL, Doolittle LK, Hammer RE, Garbers DL. Hyperactivated sperm motility driven by CatSper2 is required for fertilization. Proc Natl Acad Sci USA 2003; 100: $14869-14874$.
142. Qi H, Moran MM, Navarro B, Chong JA, Krapivinsky G, Krapivinsky L et al. All four CatSpe ion channel proteins are required for male fertility and sperm cell hyperactivated motility. Proc Natl Acad Sci USA 2007; 104: 1219-1223.

143. Avidan N, Tamary H, Dgany O, Cattan D, Pariente A, Thulliez M et al. CATSPER2, a human autosomal nonsyndromic male infertility gene. Eur J Hum Genet 2003; 11: 497-502.

144. Avenarius MR, Hildebrand MS, Zhang Y, Meyer NC, Smith LL, Kahrizi K et al. Human male infertility caused by mutations in the CATSPER1 channel protein. Am J Hum Genet 2009; 84: $505-510$.

145. Hildebrand MS, Avenarius MR, Fellous M, Zhang Y, Meyer NC, Auer J et al. Genetic male infertility and mutation of CATSPER ion channels. Eur J Hum Genet 2010; 18: 1178-1184.

146. Liu J, Xia J, Cho KH, Clapham DE, Ren D. CatSperbeta, a novel transmembrane protein in the CatSper channel complex. J Biol Chem 2007; 282: 18945-18952.

147. Wang H, Liu J, Cho KH, Ren D. A novel, single, transmembrane protein CATSPERG is associated with CATSPER1 channel protein. Biol Reprod 2009; 81: 539-544.

148. Chung JJ, Navarro B, Krapivinsky G, Krapivinsky L, Clapham DE. A novel gene required for male fertility and functional CATSPER channel formation in spermatozoa. Nat Commun 2011; 2: 153

149. Schlingmann K, Michaut MA, McElwee JL, Wolff CA, Travis AJ, Turner RM. Calmodulin and CaMKII in the sperm principal piece: evidence for a motility-related calcium/calmodulin pathway. J Androl 2007; 28: 706-716.

150. Krahling AM, Alvarez L, Debowski K, Van Q, Gunkel M, Irsen S et al. CRIS-a novel cAMP-binding protein controlling spermiogenesis and the development of flagellar bending PLoS Genet 2013; 9: e1003960.

151. Yamazaki D, Miyata $H$, Funato $Y$, Fujihara $Y$, Ikawa $M$, Miki $H$. The Mg2+ transporte CNNM4 regulates sperm $\mathrm{Ca} 2+$ homeostasis and is essential for reproduction. J Cell Sci 2016; 129: 1940-1949

152. Nishigaki T, Jose O, Gonzalez-Cota AL, Romero F, Trevino CL, Darszon A. Intracellular pH in sperm physiology. Biochem Biophys Res Commun 2014; 450: 1149-1158.

153. Miki K, Qu W, Goulding EH, Willis WD, Bunch DO, Strader LF et al. Glyceraldehyde 3phosphate dehydrogenase-S, a sperm-specific glycolytic enzyme, is required for sperm motility and male fertility. Proc Natl Acad Sci USA 2004; 101: 16501-16506.

154. Odet F, Duan C, Willis WD, Goulding EH, Kung A, Eddy EM et al. Expression of the gene for mouse lactate dehydrogenase C (Ldhc) is required for male fertility. Biol Reprod 2008; 79 : 26-34.

155. Danshina PV, Geyer CB, Dai Q, Goulding EH, Willis WD, Kitto GB et al. Phosphoglycerate kinase 2 (PGK2) is essential for sperm function and male fertility in mice. Biol Reprod 2010; 82: $136-145$.

156. Nakamura N, Dai Q, Williams J, Goulding EH, Willis WD, Brown PR et al. Disruption of a spermatogenic cell-specific mouse enolase 4 (eno4) gene causes sperm structural defects and male infertility. Biol Reprod 2013; 88: 90.

157. Narimatsu $\mathrm{H}$. Construction of a human glycogene library and comprehensive functional analysis. Glycoconj J 2004; 21: 17-24.

158. Takasaki N, Tachibana K, Ogasawara S, Matsuzaki $\mathrm{H}$, Hagiuda J, Ishikawa $\mathrm{H}$ et al. A heterozygous mutation of GALNTL5 affects male infertility with impairment of sperm motility. Proc Natl Acad Sci USA 2014; 111: 1120-1125.

159. Danshina PV, Qu W, Temple BR, Rojas RJ, Miley MJ, Machius M et al. Structural analyses to identify selective inhibitors of glyceraldehyde 3-phosphate dehydrogenase-S, a spermspecific glycolytic enzyme. Mol Hum Reprod 2016; 22: 410-426.

160. Yan W, Si Y, Slaymaker S, Li J, Zheng H, Young DL et al. Zmynd15 encodes a histone deacetylase-dependent transcriptional repressor essential for spermiogenesis and male fertility. J Biol Chem 2010; 285: 31418-31426.

161. Ayhan O, Balkan M, Guven A, Hazan R, Atar M, Tok A et al. Truncating mutations in TAF4B and ZMYND15 causing recessive azoospermia. J Med Genet 2014; 51: 239-244.

162. Kistler WS, Baas D, Lemeille S, Paschaki M, Seguin-Estevez Q, Barras E et al. RFX2 is a major transcriptional regulator of spermiogenesis. PLOS Genet 2015; 11: e1005368.

163. Wu Y, Hu X, Li Z, Wang M, Li S, Wang X et al. Transcription factor RFX2 is a key regulator of mouse spermiogenesis. Sci Rep 2016; 6: 20435.

164. Mruk DD, Wong $\mathrm{CH}$, Silvestrini $\mathrm{B}$, Cheng $\mathrm{CY}$. A male contraceptive targeting germ cell adhesion. Nat Med 2006; 12: 1323-1328.

165. O'Rand M G, Widgren EE, Sivashanmugam P, Richardson RT, Hall SH, French FS et al. Reversible immunocontraception in male monkeys immunized with eppin. Science 2004; 306: 1189-1190.

166. Bianchi E, Doe B, Goulding D, Wright GJ. Juno is the egg Izumo receptor and is essentia for mammalian fertilization. Nature 2014; 508: 483-487.

167. Matzuk MM, McKeown MR, Filippakopoulos P, Li Q, Ma L, Agno JE et al. Small-molecule inhibition of BRDT for male contraception. Cell 2012; 150: 673-684

168. Miyata H, Satouh Y, Mashiko D, Muto M, Nozawa K, Shiba K et al. Sperm calcineurin inhibition prevents mouse fertility with implications for male contraceptive. Science 2015 350: $442-445$.

169. Shang E, Salazar G, Crowley TE, Wang X, Lopez RA, Wang X et al. Identification of unique, differentiation stage-specific patterns of expression of the bromodomain-containing genes Brd2, Brd3, Brd4, and Brdt in the mouse testis. Gene Expr Patterns 2004; 4: 513-519.

170. Shang E, Nickerson HD, Wen D, Wang X, Wolgemuth DJ. The first bromodomain of Brdt, a testis-specific member of the BET sub-family of double-bromodomaincontaining proteins, is essential for male germ cell differentiation. Development 2007; 134: 3507-3515. 
171. Filippakopoulos P, Qi J, Picaud S, Shen Y, Smith WB, Fedorov $O$ et al. Selective inhibition of BET bromodomains. Nature 2010; 468: 1067-1073.

172. Lee DU, Katavolos P, Palanisamy G, Katewa A, Sioson C, Corpuz J et al. Nonselective inhibition of the epigenetic transcriptional regulator BET induces marked lymphoid and hematopoietic toxicity in mice. Toxicol Appl Pharmacol 2016; 300: 47-54.

173. Gao N, Ren J, Hou L, Zhou Y, Xin L, Wang J et al. Identification of novel potent human testis-specific and bromodomain-containing protein (BRDT) inhibitors using crystal structure-based virtual screening. Int J Mol Med 2016; 38: 39-44.

174. Castaneda J, Matzuk MM. DEVELOPMENTAL BIOLOGY. Toward a rapid and reversible male pill. Science 2015; 350: 385-386.

175. Gao Y, Zhang X, Xiong S, Han W, Liu J, Huang G. Motile sperm organelle morphology examination (MSOME) can predict outcomes of conventional in vitro fertilization: a prospective pilot diagnostic study. Hum Fertil 2015; 18: 258-264.

176. Sikka SC, Hellstrom WJ. Current updates on laboratory techniques for the diagnosis of male reproductive failure. Asian J Androl 2016; 18: 392-401. (c) (i) Cell Death and Disease is an open-access journal published by Nature Publishing Group. This work is licensed under a Creative Commons Attribution 4.0 International License. The images or other third party material in this article are included in the article's Creative Commons license, unless indicated otherwise in the credit line; if the material is not included under the Creative Commons license, users will need to obtain permission from the license holder to reproduce the material. To view a copy of this license, visit http://creativecommons.org/licenses/by/4.0/

(C) The Author(s) 2016 